\title{
УДК 619:616.
}

\section{Коколова Л.М.}

\section{ALVEOCOCCUS MULTILOCULARIS ИСТОЧНИКИ И ФАКТОРЫ ПЕРЕДАЧИ ВОЗБУДИТЕЛЕЙ}

Ключевые слова: лтлтлтлтAlveococcus multilocularis - Альвеолярный эхинококкоз, Echinococcus multilocularis, возбудитель болезни, человек, белый песец, красная лисица, собака, лемминг, мышевидные грызуны, Якутия.

Резюме: Возбудитель альвеококкоза выделен в самостоятельный род совсем недавно, до этого его, благодаря сходству, по классификацию тений относили к роду Echinococcus - эхинококков и называли Echinococcus multilocularis. Источником возбудителя альвеолярного эхинококкоз грызунов, насекомоядных и приматов (человека и др.) промежуточных хозяев Alveococcus multilocularis являются хищные плотоядные - белые полярные песцы, лисицы, собаки окончательные хозяева тениид, выделяющие во внешнюю среду с фекалиями онкосферы альвеококка. В отличие от эхинококкоза у альвеококкоза распространение очаговое. Очаги альвеококкоза в России зарегистрированы в Западной Сибири, Красноярском, Хабаровском краях, Магаданской области, Чукотке и Якутии.

Изучая эколого-эпизоотическую обстановку по зоонозным гельминтозам в условиях вечной мерзлоты, дана характеристика природных очагов альвеококкоза, проведен анализ и прогнозирования развития эпизоотической ситуации в природных комплексах. Определены основные источники и факторы передачи альвеококкоза у восприимчивых животных и закономерпность циркуляции возбудителей в природных очагах.

Таким образом, на территории Якутии находятся природные очаги альвеококкоза. По прогнозам специалистов, практически все они располагают эпизоотическим потенциалом, достаточным для внезапного обострения эпизоотической обстановки в регионе. Поэтому необходимость возобновления мониторинга природных очагов альвеолярного эхинококкоза представляется весьма актуальной.

Цель нашего исследования изучить особенности распространения особо опасных зоонозных гельминтозов - альвеококкоза (альвеолярного эхинококкоза), для снижения риска заражения возбудителями зоонозов животных и человека с учетом природно-климатических условий и социально-экономических преобразований в Якутии.

\section{Введение}

В XIX веке многие европейские патологи, включая Bйhl (1852), Luschka (1856), описали специфическую и иредкую опухоль печени, которую 
назвали «альвеолярная карциома», т.е. опухоль имеющее ячеистое строение, в 1855 году Virchow обнаружил в опухоли крючья эхинококка и высказал, что опухоль имеет паразитарную природу и подсчитал, что является одним из разновидностей личиночной формы цестоды Taenia echinococcus известной теперь как Echinococcus granulosus и назвал опухоль «язвенная мультилокулярная гидатида». Другие исследователи, использовали материалы исследования Posselt (1890) для утверждения двух разных гипотез и определили морфологическое отличие, потому был выдвинут аргумент в поддержке самостоятельности вида Alveococcus multilocularis, к тому основным поводом послужило специфическое географическое распространение этого вида. В 1960 году К.И. Абуладзе (1960), используя материалы В.В. Никитина, проконсультировавшись с К.И. Скрябиным обосновал новый род Alveococcus с одним видом Alveococcus multilocularis (Leuckart, 1863) Abuladse, 1960, a Echinococcus multilocularis перевел в синонимы [1, с.312-367].

\section{Материалы и методики исследования}

При выполнении исследований изучали материалы собранные самостоятельно это органы и ткани от диких плотоядных животных ( белых песцов, красных лисиц, волков, рыси, росомахи) и тушки мелких грызунов (сибирских леммингов, полевых мышей) проведены исследование собак и кошек в оленеводческих, охотничье промысловых хозяйствах, сельских населенных пунктов, материалы для изучения альвеолярного эхинококкоза были представлены в хирургическом отделении и в специализорованных отделениях судебно медицинской экспертизы ЯРЦЭМ №1 и №2.

Гельминтологические исследование органов и тканей животных, тушек грызунов фекалий, проводили общепринятыми методами: гельминтоовоскопии фекалий, мазка, Фюллеборна, последовательного промывания, Дарлинга, полного и неполного вскрытия по К.И. Скрябину.

Всего исследовано по видам:

Отряд Хищные Carnivora, сем. Собачьи Canidae: белый песец (Alopex lagopus) - 834; лисица красная Vulpes vulpes - 28; собака Canis familaris 2678; волк Canis lupus- 245; gulo;

Сем. кошачьи Filedae: кошка Files catus - 593; рысь Files lynx - 3; Gulo

Отряд Грызуны Rodentia сем. Muridae: темная полевая мышь Misrotus agrestus - 1019; красная полевка Misrotus rugestus - 212; сибирский лемминг Lemmus sibiricus - 784; тундровая бурозубка Sorex tundrensis - 47.

\section{Результаты и обсуждение}

Со времени первых публикаций о находок альвеококка прошло более 100 лет, по данным Н.П. Крыловой-Дюк за период с 1901 по 1939 годы в России было опубликовано более 300 наблюдений альвеококка печени, и по 
числу публикаций большее число авторов занимает сибирская школа, так как с 1888 года в городе Томске был научный и лечебный центр Сибири [2,3 c. 16-25]. В последующие годы число наблюдений значительно возросло, стали публиковаться труды якутских исследователей В.С. Семенова, Б.И. Альперовича, П.П. Габышева, анализ данных с 1958-1964 г. подтверждает о существовании очагов альвеококкоза, это были крупные очаги с регистрацией от 213 до 811 больных, в это время среднем по республике на одну тысячу населения приходился 1,66 заболеваний альвеококкозом. В настоящее время, альвеококкоз в природе распространен не повсеместно, в России встречается в Татарстане, Башкирии, Сибири (Омская, Томская, Новосибирская, Иркутская области, Красноярский край) и на Дальнем Востоке (Якутия, Магаданская область, Хабаровский край). Распространен альвеококкоз в Японии, Канаде, Германии и Австрии, Казахстане и Киргизии.

Морфофизиологическая характеристика Alveococcus multilocularis. Ленточная форма очень сходна с эхинококком. Отличительные признаки: количество крючьев на сколексе и шаровидная форма матки, отсутствие на члениках боковых выпячиваний, расположение полового отверстия в передней части бокового края, а также по строению альвеококковой цисты на органах у промежуточного хозяина. Циста (опухоль) представляет собой конгломерат стоящий из мелких пузырьков, заключенных в общую соединительную капсулу - строму. Циста не полая, не содержат жидкости, имеет внутренние почкующие плотные пузырьки содержающий протосколекс альвеококка, прорастающий по типу злокачественной опухоли.

Окончательный хозяин - песец, лисица, собака, промежуточный мышевидные грызуны, а также человек.

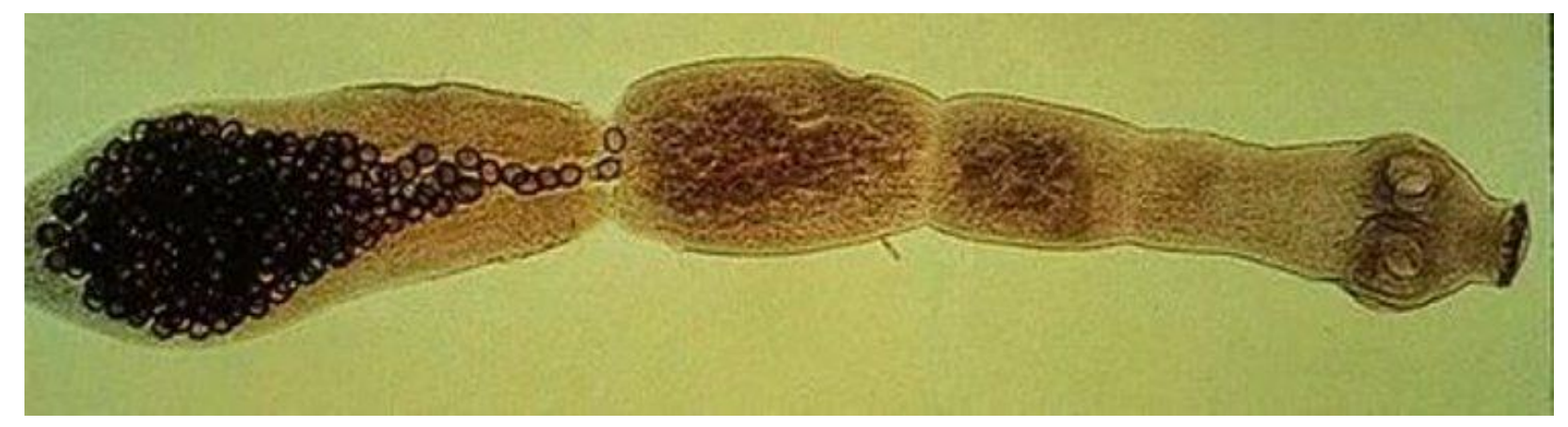

Рис. 1. Половозрелая цестода Alveococcus multilocularis у лисицы красной

Объекты наших исследований - белый песец (Alopex lagopus) всего вскрыто 834 особей, из них альвеококки были обнаружены у 818 особей, что составило $98,1 \pm 0,98 \%$ интенсивность инвазии составляло более $15900 \pm 3261$ экз.; лисица красная Vulpes vulpes исследовано 28 особей альвеококки обнаружили у 1 лисицы, что составляет 5,5\% интенсивность инвазии было 1807 экз.; собака Canis familaris - 2678 из них у 356 (13,3\%) обнаружены различные виды гельминтов, Alveococcus multilocularis не было обнаружено; волк Canis lupus всего нами исследовано 361 волк, но Alveococcus 
multilocularis не было обнаружено, у 231 (61\%) волка обнаружены эхинококки Echinococcus granulosus.

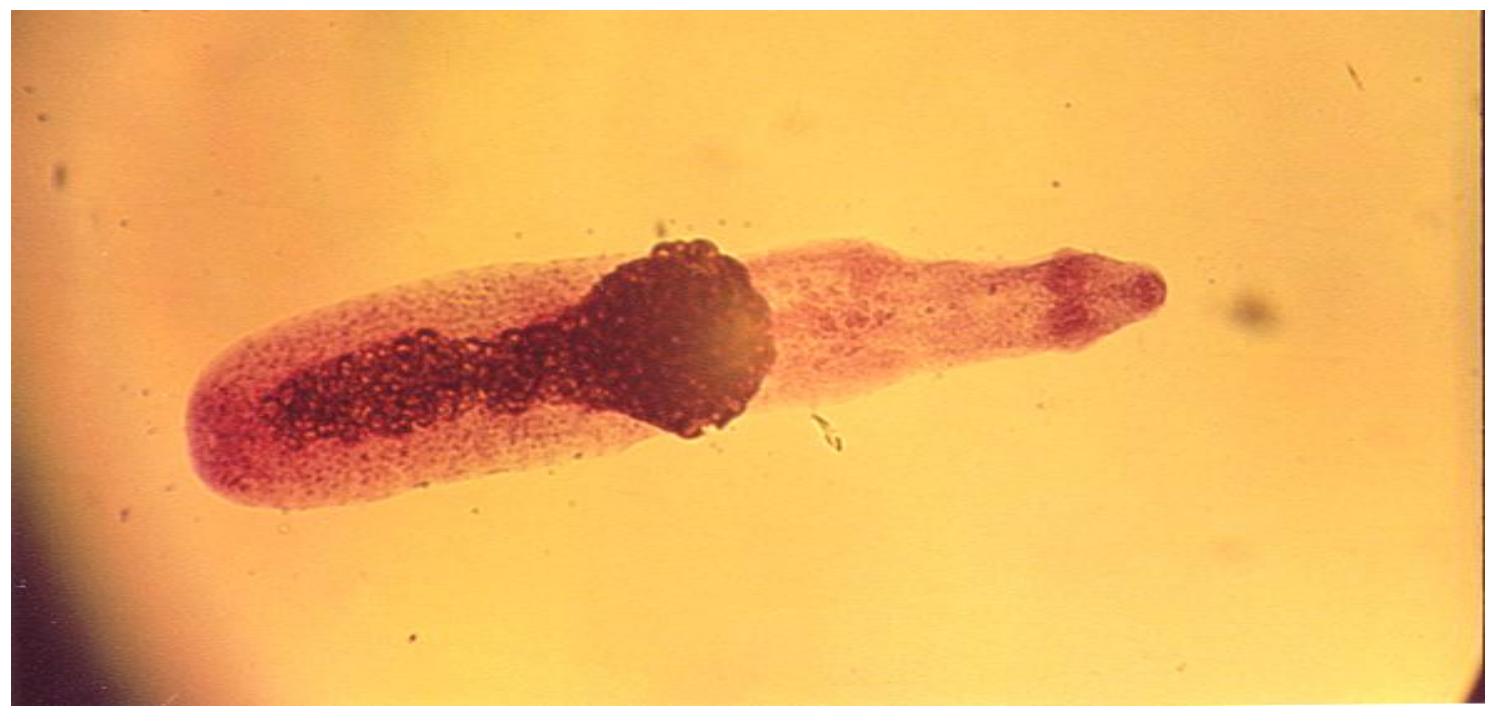

Рис. 2. Половозрелая цестода Alveососcus multilocularis у белого песца

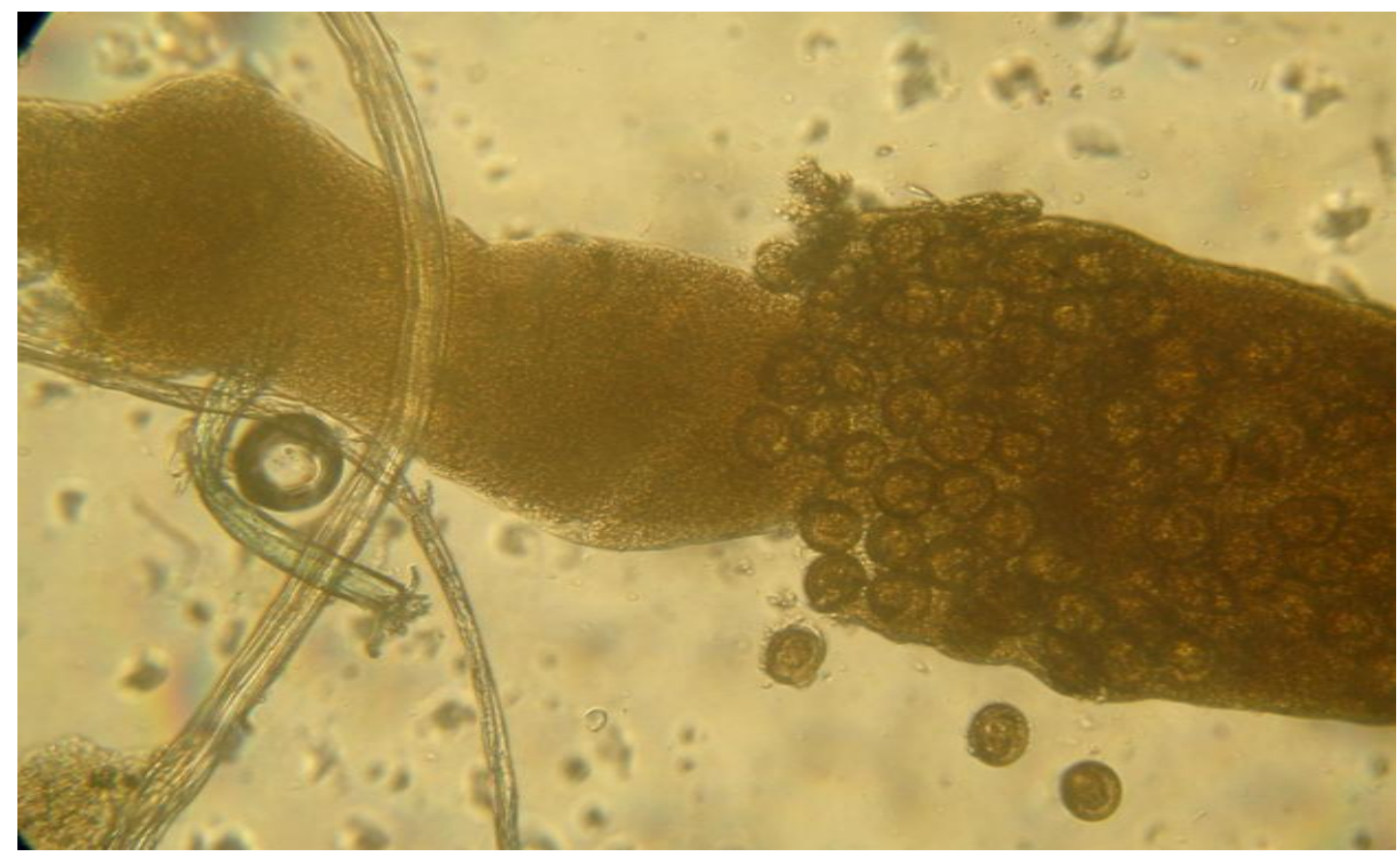

Рис. 3. Выход онкосфер (яиц) из наполненного членика Alveococcus multilocularis (паразитирующего у белого песца)

Альвеококкоз встречается часто у белых полярных песцов окончательных хозяев, и леммингов у промежуточных хозяев, у лисиц и собак и других мышевидных грызунов реже, чем эхинококкоз [7, с91-96], у человека и других млекопитающих животных почти не регистрируется, 1 случай заболевания человека регистрированный в 2014 году (диагноз поставлен посмертно), болезнь характеризовалась злокачественным течением более 10-15 лет, пораженный орган - печень, с характерным метастазированием в другие органы - кишечник и брюшина. Величина узлов альвеококка достигало в диаметре $15-20 \mathrm{~cm}$. 
Данные полученные Губановым и Сафроновым по изучению альвеококка в Якутии, что вид относится к виду Alveococcous multilocularis (Leuckrart, 1863) Abuladze ,1960), дальнейшее изучение инвазии по природной очаговости и его распространенности, по морфологической характеристике разности формы и расположении матки к выводу о существовании на территории Якутии двух штаммов альвеококков циркулирующий между красная лисица (собака) - мышевидные грызуны таежного штамма (в таежной зоне Якутии) (рис. 1) и белыми песцами (собаками) - сибирским леммингов тундрового штамма (в тундровой зоне Якутии) (рис. 2).

Выводы и заключение. Таким образом, альвеококки распространены у диких и домашних плотоядных животных и заболевание является природноочаговым. Цикл развития не сильно отличается от эхинококка. Человек заражается во время охоты на песцов, при разделке шкурки, инвазированными онкосферами (зараженными яйцами) альвеококка, также при общении с зараженными альвеококками собаками, когда допускают их в помещение (дома, яранги и др.) или через инвентарь, когда их используют их, как ездовых собак. Мышевидные грызуны являются промежуточные хозяева альвеококка заражаются, поедая пищу загрязненную фекалиями, содержащую онкосферы альвеококка. Заражение окончательных хозяев песцов, лисиц и собак происходит при поедании мышевидных грызунов.

\section{Библиографический список}

1. Абуладзе К.И. Основы цестологии. IV. Тениаты - ленточные гельминты животных и человека и вызываемые ими заболевания / К.И. Абуладзе - М.: «Наука», 1964. - С 312-367.

2. Альперович Б.И. Альвеококкоз. / Б.И. Альперович - Я.: Якутское книжное издательство, 1967. - 223 с.

3. Альперович Б.И. Альвеококкоз и его лечение. / Б.И. Альперович - М.: Медицина, 1972. - 272 с.

4. Бессонов А.С. Альвеолярный эхинококкоз (Echinococcus multilocularis) и гидатоз. / А.С. Бессонов - М.: Россельхозакадемия, 2003. $334 \mathrm{c}$.

5. Губанов Н.М. Зараженность альвеококкозом хищных млекопитающих и мышевидных грызунов в Якутии. / Н.М. Губанов // Докл. научн. конф. посв 80-летию Скрябина К.И. Сборник научных трудов. Москва. - 1960. - С. 41-42.

6. Исаков С.И., Сафронов М.Г. Эхинококкоз и альвеококкоз животных в Якутии / С.И. Исаков, М.Г. Сафронов // Научн.- практ. семинар 
«Перспективы ликвидации потерь от эхинококкоза в животноводстве» Тезисы докладов. г. Фрунзе, 14-16 окт.1987. - Москва. - 1987. - С.23.

7. Коколова Л.М. Особенности распространение зоонозных гельминтозов на Крайнем Севере./ Л.М. Коколова // Труды Всерос. ин-та гельминтол.- М.: Россельхозакадемия, т.41. - 2006. - С.91-96.

8. Овсюкова Н.И. Природный очаг альвеолярного эхинококкоза на Чукотке. / Н.И. Овсюкова //Мед. паразитология и паразитарные болезни. Москва. -1961. - № 2 - С.226.

\section{References:}

1. Abuladze K. I. Osnovi cestodologii. IV. Teniatya - lentochnsy gelminte givotnych I cheloveka I vyzyvaemie imi zabolevanie - Moscow. - «Science.» 1964. - 312-367.

2. Alperovich B. I. Alveococcosis. - Ya.: Yakutskoe kniznoe izdanie, 1967. $-223 \mathrm{~s}$.

3. Alperovich B. I. Alveococcosis i ego lechenie. / B.I. Alperovich - M.Medicine, 1972. - $272 \mathrm{p}$.

4. Bessonov A. S. Alveolarnii echinococcos (Echinococcus multilocularis) i hydatosis. / A.S. Bessonov - M.: Rosselchozacademya, 2003. - 334 s.

5. Gubanov N. M. Zarazennosti alveococcosom chichnich mlecopitaichix I michevidnich gryzinov v Yakutii. / N. M. Gubanov // Doklad naych. conf. posv. 80-letii K. I. Skryabina. Sbornik nauchnich trudov. - Moscow. - 1960. - S. 41-42.

6. Isakov S. I., Safonov M. G. Echinococcos I alveococcos givotnich Yakutii / S. I. Isakov, M. G. Safronov // Nauch.-prakt. Seminar «Perspectivy likbidasii poteri ot echinococcosa v zhivotnovodstve» Tezisy dokladov, g. Frynze, 14-16 oct.1987. - Moscow. - 1987. - S. 23.

7. Kokolova L. M. Osobennosti rasprostranenia zoonoznich helmintov na Krainem severe. / L.M. Kokolova // Tr. Vserossiiskogo institute helminthol.- M.: Rosselkhozakademia, tom. 41. - 2006. - P. 91-96.

8. Ovsukova N.I/ Prirodnii ochag alveolarnogo echinococcosa v Chukotke. //Med. Parasitologya i parasitarnye bolezni. - Moscow. -1961. - № 2 - s. 226.

\section{Kokolova L. M.}

\section{ALVEOCOCCUS MULTILOCULARIS SOURCES AND FACTORS OF TRANSMISSION OF PATHOGENS}

Keywords: Alveococcus multilocularis - Echinococcus multilocularis, pathogen of humanis, Alopex lagopus, Vulpes vulpes, Canis familaris, Lemmus sibiricus, Muridae, Yakutia.

Abstract: the Causative agent of alveococcus is isolated in an independent parent recently, before it, due to similarity, according to the classification of teni attributed to the genus Echinococcus - Echinococcus and called Echinococcus multilocularis. The source of the causative agent of alveolar hydatigena disease of rodents, insectivores and primates (human etc.) intermediate hosts Alveococcus 
multilocularis are predatory carnivores - white polar foxes, foxes, dogs are definitive hosts of taenii emitting into the environment with feces oncospheres of alveolari. In contrast of echinococcus from alveococcus of the focal distribution. Centers of alveococcus in Russia are registered in Western Siberia, Krasnoyarsk, Khabarovsk territories, Magadan region, Chukotka and Yakutia. Studying ecologoepizootic situation on zoonotic helminthis in permafrost conditions, the characteristic of natural foci of alveococcus is given, the analysis and forecasting of epizootic situation development in natural complexes is carried out. The main sources and factors of alveococcus transmission in susceptible animals and the regularity of pathogens circulation in natural foci were determined. Thus, in Yakutia there are natural foci of alveococcus. According to experts, almost all of them have epizootic potential sufficient for a sudden exacerbation of the epizootic situation in the region. Therefore, the need to resume monitoring of natural foci of alveolar echinococcus seems very urgent.

\section{Сведение об авторе:}

Коколова Людмила Михайловна, доктор ветеринарных наук, заведующая лабораторией гельминтологии ФГБНУ «Якутский научно-исследовательский институт сельского хозяйства имени М.Г. Сафронова»; д. 23/1, ул. Бестужево-Марлинского, Якутск, Россия, 677001; тел.: +7914 30038 16; +7 (411) 2214572; e-mail: kokolova_lm@ mail.ru

Ответственный за переписку с редакцией: Коколова Людмила Михайловна, тел.: +79143003816; e-mail: kokolova_lm@mail.ru

\section{Author affiliation:}

Luidmila Michailovna Kokolova, D.Sc. in Veterinary Medicine, head of helminthology laboratory of the Yakutsk Institute agricultural; 23/1, BestuzevjMarlinskogo st., Yakutsk, Russia, 677001; phone: +7 (914) 30038 16; e-mail: kokolova_lm@mail.ru 